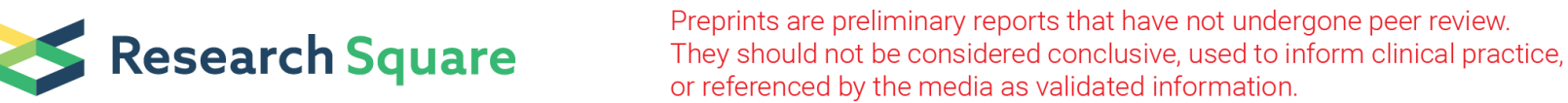

\section{Angiotensin Converting Enzyme Inhibitors and Angiotensin Receptor Blockers and The Risk of SARS-CoV-2 Infection: A Systematic Review and Meta-analysis}

Imad M. Tleyjeh ( $\square$ itlaygeh@gmail.com )

King Fahad Medical City

Aref A. Bin Abdulhak

Swedish Heart and Vascular Institute

Haytham Tlayjeh

King Abdulaziz Medical City

Mouaz H. Al-Mallah

Houston Methodist DeBakey Heart and Vascular Center

M. Rizwan Sohail

Mayo Clinic College of Medicine and Science

Tarek Kashour ( $\nabla$ tkashour@googlemail.com )

King Saud University Medical City

Systematic Review

Keywords: Coronavirus, COVID-19, Angiotensin converting enzyme inhibitors, Angiotensin receptor blockers

Posted Date: May 20th, 2020

DOI: https://doi.org/10.21203/rs.3.rs-29529/v1

License: (c) (i) This work is licensed under a Creative Commons Attribution 4.0 International License. Read Full License 


\section{Abstract}

Importance:

SARS-CoV-2 virus gains access and infects target cells via angiotensin converting enzyme 2 (ACE2) receptor. Because angiotensin converting enzyme inhibitors (ACEIs)/angiotensin receptor blockers (ARBs) could increase the expression of ACE2, there are growing concerns that their use could increase the risk of SARS-CoV-2 infection. Cardiac societies have called for epidemiological research about this emerging controversy.

Objective:

We sought to systematically review the literature and perform a meta-analysis about prior use of ACEI/ARBs and risk of SARS-CoV-2 infection.

Data source:

We searched multiple data sources including PubMed, ClinicalTrial.org , and medrxiv.org from November 2019 through May 16, 2020.

Study selection:

Any study that reported on the adjusted association of prior use of ACEls / ARBs and risk of acquiring SARS-CoV-2 infection was eligible. Two authors independently reviewed eligible studies and extracted data into a prespecified data collection form.

Data synthesis:

An inverse variance meta-analytic approach was used to pool adjusted odds ratios using a random effect model meta-analysis. $\left.\right|^{2}$ test was used to assess in-between studies heterogeneity. The NewcastleOttawa quality assessment scale (NOS) was used to assess the quality of included studies.

Main outcome and Measures:

The association between the prior use of ACEls or ARBs and risk of SARS-CoV-2 infection was assessed using pooled OR and 95\% confidence interval.

Results:

Six case control studies that enrolled a total of 5657 patients (2536 patients in ACEls arm and 3121 patients in ARBs arm ) and 721,859 controls were included in our meta-analysis. Two of the included studies were from the USA, one from Italy, one from China, one from Spain, and one from South Korea. All included studies scored high based on NOS scale. Prior use of ACEls was not significantly associated with an increased risk of SARS-CoV-2 infection, OR 0.93, $\mathrm{Cl}(0.85,1.02), \mathrm{I}^{2}=20 \%$. Similarly, prior use of 
ARBs was not significantly associated with an increased risk of SARS-CoV-2 infection, OR $0.86, \mathrm{Cl}$ $(0.67,1.10), I^{2}=93 \%$. Sensitivity analysis was performed by removing a study that could have been affected by residual confounding; OR for ARB $1.04, \mathrm{Cl}(0.96,1.12), \mathrm{I}^{2}=32 \%$.

\section{Conclusion:}

Findings from this systematic review and meta-analysis suggest that prior use of ACEls or ARBs is not associated with a higher risk of COVID-19. Our results are in support of the recent recommendations of cardiac societies and provide a reassurance to the public not to discontinue prescribed ACEls/ARBs due to fear of COVID-19.

\section{Introduction}

Severe acute respiratory syndrome coronavirus-2 (SARS-CoV-2) is the causative pathogen for COVID-19 pandemic. SARS-CoV-2 belongs to Betacoronavirus genus and SARS related coronavirus species ${ }^{1}$. The virus is highly contagious, has infected millions of people globally, and is causing devastating outcome with hundreds of thousands of fatalities worldwide.

SARS-CoV-2 gains access and infect the target cells via angiotensin converting enzyme 2 (ACE2) receptor

2 , a membrane-bound protein found on the surface of type 2 pneumocytes, epithelial cells, and enterocytes. Once viral replication starts, damage to host cells is caused by both direct viral cytopathic effect and host immune response resulting in cytokine storm. Treatment with angiotensin converting enzyme inhibitors (ACEI) or angiotensin receptors blockers (ARB) has been shown to increase ACE2 expression by up to 2 to 5 fold $^{4-6}$. Moreover, the 3D structure studies of SARS-Cov- 2 demonstrated that it has a better binding stability than SARS-CoV-1 virus with 10-15 times higher estimated binding affinity to ACE2 7,8 .

These findings coupled with several observations of the high prevalence and mortality among SARS-CoV2 infected patients with underlying cardiovascular disease (CVD) have led to a speculation that ACEIs/ARBs may predispose to higher risk of being infected with SARS-CoV-2 and more severe COVID-19 disease given the widespread use of these medications among patients with underlying CVD 9,10 .

Despite these theoretical concerns, several major cardiac societies have cautioned patients and physicians not to discontinue these drugs in patients already taking these medications, ${ }^{11,12}$, although no epidemiological data were available at that time to support their recommendations. Subsequently, emerging epidemiological studies have not identified a significant association between prior use of ACEIs/ARBs and development of COVID-19. However, studies might have been underpowered to detect such an association. Therefore, we systematically reviewed the literature and performed a meta-analysis of the association between prior use of ACEls and ARBs and development of COVID-19.

\section{Methods}


We searched multiple electronic databases including Pubmed, ClinicalTrial.org, and medrxiv.org using the following terms (" coronavirus " OR "covid-19" OR "SARS” AND “ Angiotensin" OR "Angiotensins" ) from November 2019 through May 15,2020. Any clinical study in humans that reported an the association between prior use of ACEl and/or ARB and the risk of SARS-CoV-2 infection were eligible for inclusion if it reported an adjusted effect estimate.

We followed Preferred Reporting Items for Systematic Reviews and Meta-analyses (PRISMA) ${ }^{13}$ and MetaAnalysis of Observational Studies in Epidemiology guidelines for reporting systematic review and metaanalysis of observational studies guidelines ${ }^{14}$. Two authors independently $(A B, H T)$ extracted the data into a prespecified data collection form. We collected data about study's population and characteristics, exposure to ACEls and or ARBs, and outcome (development of COVID-19)

The eligible studies were assessed according to the Newcastle-Ottawa quality assessment scale $(\mathrm{NOS})^{15}$. NOS scale rates case-controls studies based on 3 parameters: selection of cases and controls, comparability between the cases and controls, and exposure assessment. It assigns a maximum of 4 stars for selection, 2 stars for comparability, and 3 stars for exposure assessment.

Studies with less than 5 stars were considered low quality, 5-7 stars moderate quality, and more than 7 stars high quality. Two reviewers (AN and HT) assessed the quality of the included studies.

Adjusted odds ratios (OR) with corresponding 95\% confidence interval from included studies were pooled into a random effects model inverse variance meta-analytic approach. The outcome of interest was the association between prior use of ACEls and ARBs and risk of infection with SARS-CoV-2. We reported pooled adjusted effect estimates separately for ACEls and ARBs.

Heterogeneity among the included studies was assessed using $\chi^{2}$ and $\mathrm{I}^{2}$ tests. The $\mathrm{I}^{2}$ statistic describes the proportion of variation in treatment estimate that is not related to sampling error ${ }^{16}$. A value of zero indicates no heterogeneity, 25\%-49\% low, 50\%-74\% moderate, and 75\% a high degree of heterogeneity. No formal assessment of publication bias was performed because of the low number of studies as per Cochrane guidelines.

Two-sided P value of < 0.05 was considered statistically significant for all included analyses. The statistical software Review Manager, version 5.3.5 (The Nordic Cochrane Center, The Cochrane Collaboration, 2018, Copenhagen, Denmark) was used for all analyses.

\section{Results}

Six case control studies ${ }^{17-23}$ that enrolled a total of 5657 patients (2536 patients in ACEls arm and 3121 patients in ARBs arm ) and 721,859 controls were included in our meta-analysis. Figure 1 shows the result of our search strategy. Table 1 illustrates the general characteristics of the included studies. Two of the included studies were from the USA, one from Italy, one from China, one from Spain, and one from South Korea. All studies have reported an adjusted OR for ACEIs and ARBs separately. Table 2 shows the 
analytical approaches used in each study and its methodological quality. All included studies scored high based on NOS scale.

Prior use of ACEls was not significantly associated with an increased risk of acquiring SARS-CoV-2 infection, OR $0.93, \mathrm{Cl}(0.85,1.02)$ with no significant degree of between studies heterogeneity, $\mathrm{I}^{2}=20 \%$ (Figure 2). Similarly, Prior use of ARBs was not significantly associated with an increased risk of acquiring SARS-CoV-2 infection, OR $0.86, \mathrm{Cl}(0.67,1.10)$ with high degree of between studies heterogeneity $\mathrm{I}^{2}=93 \%$ (Figure 3 ). Sensitivity analysis was performed by excluding the study by Yan et al. in an attempt to explain the high degree of heterogeneity. The OR for ARB use in the study by Yan et al. was only adjusted for age, sex and BMI and therefore, could have been affected by residual confounding. Pooling studies without the study by Yan et al. showed that ARBs use was not significantly associated with an increased risk of acquiring SARS-CoV-2 infection, OR 1.04, $\mathrm{Cl}(0.96,1.12)$ with mild degree of between studies heterogeneity $\mathrm{I}^{2}=32 \%$.

\section{Discussion}

Findings from our systematic review and meta-analysis suggest that prior use of ACEls or ARBs is not associated with a higher risk of COVID-19. Our pooled effect estimates are precise with narrow confidence intervals which argues against the possibility of underpowered findings. Our results are in support of the recent recommendations of cardiac societies not to discontinue ACEI or ARB in patients who have indications for their use because of COVID-19 concerns ${ }^{11,12}$.

The hypothesis that the use of ACEls or ARBs is associated with a higher risk of COVID-19 emerged based on two facts from multiple previous studies. First, the observations that ACEls or ARBs upregulate the expression of ACE2. Second, the high prevalence of comorbidities such as hypertension, diabetes, and ischemic heart disease among COVID-19 patients where these drugs are commonly used. However, this hypothesis is an oversimplification of a very complex interaction of multiple signaling pathways involved in SARS-COV-2 infection and COVID-19 disease.

Several possible explanations can be offered for the possible lack of association between ACE2 expression and the risk of COVID-19. Increased ACE2 protein expression does not necessarily mean increased number of ACE2 molecules on the cell membrane since the ACE2 cell membrane density is determined not only by the gene expression and protein production but also by the rate of ACE2 shedding from the cell membrane. It is well established that ACE2 is cleaved at the cell membrane by the metalloprotease ADAM17 generating soluble ACE2 that is released into the circulation. ADAM17 expression and activity can alter ACE2 shedding and consequently may affect cell membrane ACE2 density 24 .

Another possible explanation would be that even if ACEls or ARBs increase the risk of SARS-CoV-2 infection, it is conceivable that many of these cases are mild or asymptomatic and therefore not tested and go undiagnosed. This is due to the fact that ACEls and ARBs seem to exert protective effect against 
severe COVID-19 through modulation of inflammatory and immune responses. ACEls and ARBs have been shown to influence several signaling pathways involved in inflammation and the regulation of immune responses, which include nuclear factor Kappa-B, mitogen activated protein kinases and Roh/ROCK pathway. These effects result in reduction in inflammatory cytokines, TNF-alpha, IL-1beta and IL-6, inhibition of dendritic cell maturation and Th1 and Th17 cell polarization responses, and suppression of Rho/ROCK pathway ${ }^{25-27}$. Additionally, in one study, losartan inhibited dendritic cell maturation and Th1 and Th17 cell polarization responses ${ }^{26}$. These inflammatory and immune modulating effects of ACEls and ARBs may have clinical relevance in the context of COVID-19 disease.

Moreover, ACE2 is a well-known cardioprotective protein as it mediates vasodilatory, anti-fibrotic, immune modulating, anti-inflammatory, and anti-proliferative effects. These effects are realized through conversion of angiotensin-II to angiotensin-(1-7) peptide and angiotensin I to angiotensin-(1-9) peptide which leads to reduction in angiotensin II levels. In addition, angiotensin-(1-7) peptide activates Mas receptor through which it exerts its cardiovascular protective effects ${ }^{28}$. Interestingly, Angiotensin II is proinflammatory and has been shown to play a significant role in the pathogenesis of acute lung injury/adult respiratory distress syndrome (ARDS) in several animal models including SARS-CoV-1. Conversely administration of ARBs and ACE2 were protective in animal model studies ${ }^{29}$. It was intriguing that it has been reported recently that COVID-19 patients exhibit high levels of angiotensin II and was associated with higher viral load and lung injury ${ }^{30}$. Hence, up-regulation of ACE2 expression by ACEls and ARBs may have lung protective effects against SARS-CoV-2 triggered acute lung injury. In a recent systematic review and meta-analysis, we observed that use of ACEIs/ARBs is associated with a decreased risk of death or critical outcome among SARS-CoV-2 infected patients ${ }^{31}$.

We observed a high degree of heterogeneity for the pooled effect estimate of the ARB use and COVID-19 due to the study by Yan et al. The study by Yan et al. from China reported lower effect estimates as compared to the other identified studies and this could be related to residual confounding or an underlying biological explanation. The OR for ARB use in the study by Yan et al. was only adjusted for age, sex and BMI and therefore, could have been affected by residual confounding. On the other hand, it has been shown in a, Chinese population that rs $12692386 \mathrm{G}$ promotor polymorphism was associated with higher ADMA17 expression ${ }^{32}$. Moreover, several ACE2 polymorphisms have been reported in different populations including the Chinese. These polymorphisms have been shown to be associated with HTN, DM and CVD as well as with ACE2 activity, and serum ACE2 and angiotensin-(1-7) peptide levels ${ }^{33}$.It remains to be determined whether increased circulating ACE2 levels are due to increased shedding or due to both increased shedding and expression. Notwithstanding, these differences in regulatory processes of ACE2 may modify membrane ACE2 density and theoretically, could influence susceptibility to SARS-CoV2 infection. Lastly, SARS-CoV-2 needs not only ACE2 but it is also dependent on the serine protease TMPRSS 2 and it has been demonstrated that inhibition of TMRSS2 blocks SARS-CoV-2 cell entry ${ }^{34}$. Thus, factors regulating TMRSS2 expression or its enzymatic activity would modulate SARSCoV-2 infectivity. For example, TMPRSS2 expression is regulated by androgens and has been reported in a recent study that men treated with antiandrogenic therapy were less susceptible to CoV-2 infection ${ }^{35}$. 
Accordingly, population differences in testosterone levels, androgen receptor function and it's downstream signaling pathway could affect TMPRSS2 levels and hence susceptibility to SARS-CoV-2 infection.

Our systematic review has several strengths. First, the hypothesis that treatment with ACEI or ARB increases ACE2 expression by several folds and therefore increases the risk of COVID-19 can only be feasibly tested using an observational study design similar to studies included in our meta-analysis. It is not conceivable to randomize patients for years of ACEI or ARB use vs. control groups to see if they are at a higher risk for COVID-19. Second, we included all published studies including pre-prints. Third, we pooled only adjusted effect estimates to decrease the chance of confounding effect. Fourth, the pooled effect estimates were very precise. Nevertheless, inferences from our meta-analysis could be weakened by limitations inherent to the meta-analysis and the individual studies. Given the observational design of included studies and retrospective data collection, the possibility that the observed association between ACEI/ARB use and COVID -19 was affected by bias or confounding should be considered. For example, comorbidities and severity of illness are known confounders that are associated with ACEI/ARB intake and mortality and the healthy user effect could theoretically explain a potential role for ACEI/ARB in infection outcome. However, the opposite could also be the case where the sicker patients have more exposure to ACEI/ARB because patients with hypertension and cardiovascular risk factors have higher risk for COVID. Although we have pooled effect estimates from regression models that adjusted for possible confounders including age, comorbidities and medications-although the models were not uniform - residual confounding cannot be fully excluded. Finally, the presence of publication bias is very unlikely during this pandemic, where to date (May 15,2020) 3477 articles about COVID-19 were published on pre-print servers (2790 medRxiv, 687 bioRxiv).

Despite the recommendations of major cardiac societies advising patients and physicians not to discontinue ACEI or ARB because of fear of COVID-19, recent data from at least one large cohort of 5700 patients with COVID-19 admitted to 12 hospitals in New York between March 1, 2020, and April 4, 2020, have shown otherwise. In this cohort, of the patients who were taking an ACEI or ARB prior to hospitalization, only (48.1\%) continued taking an ACEl while in the hospital and (50.1\%) continued taking an ARB while in the hospital ${ }^{36}$.

\section{Conclusions}

Findings from this systematic review and meta-analysis suggest that prior use of ACEls or ARBs is not associated with a higher risk of COVID-19. Our results are in support of the recent recommendations of cardiac societies and provide a reassurance to the public not to discontinue prescribed ACEls/ARBs due to fear of COVID-19.

\section{Declarations}

There is no conflict of interest to declare. 


\section{References}

1. Viruses CSGotICoTo. The species Severe acute respiratory syndrome-related coronavirus: classifying 2019-nCoV and naming it SARS-CoV-2. Nat Microbiol. 2020;5(4):536-544.

2. Li W, Moore MJ, Vasilieva $\mathrm{N}$, et al. Angiotensin-converting enzyme 2 is a functional receptor for the SARS coronavirus. Nature. 2003;426(6965):450-454.

3. Patel VB, Zhong JC, Grant MB, Oudit GY. Role of the ACE2/Angiotensin 1-7 Axis of the ReninAngiotensin System in Heart Failure. Circ Res. 2016;118(8):1313-1326.

4. Ferrario CM, Jessup J, Chappell MC, et al. Effect of angiotensin-converting enzyme inhibition and angiotensin II receptor blockers on cardiac angiotensin-converting enzyme 2. Circulation. 2005;111(20):2605-2610.

5. Ishiyama Y, Gallagher PE, Averill DB, Tallant EA, Brosnihan KB, Ferrario CM. Upregulation of angiotensin-converting enzyme 2 after myocardial infarction by blockade of angiotensin II receptors. Hypertension. 2004;43(5):970-976.

6. Esler M, Esler D. Can angiotensin receptor-blocking drugs perhaps be harmful in the COVID-19 pandemic? J Hypertens. 2020;38(5):781-782.

7. Lan J, Ge J, Yu J, et al. Structure of the SARS-CoV-2 spike receptor-binding domain bound to the ACE2 receptor. Nature. 2020.

8. Shang J, Ye G, Shi K, et al. Structural basis of receptor recognition by SARS-CoV-2. Nature. 2020.

9. Bonow RO, Fonarow GC, O'Gara PT, Yancy CW. Association of Coronavirus Disease 2019 (COVID-19) With Myocardial Injury and Mortality. JAMA Cardiol. 2020.

10. Vaduganathan M, Vardeny O, Michel T, McMurray JJV, Pfeffer MA, Solomon SD. Renin-AngiotensinAldosterone System Inhibitors in Patients with Covid-19. N Engl J Med. 2020;382(17):1653-1659.

11. Bozkurt B. HFSA/ACC/AHA Statement Addresses Concerns Re: Using RAAS Antagonists in COVID19. https://www.acc.org/latest-in-cardiology/articles/2020/03/17/08/59/hfsa-acc-aha-statementaddresses-concerns-re-using-raas-antagonists-in-covid-19. Published 2020. Accessed May 15,2020, 2020.

12. de Simone G, Kovacs R, Harrington B. Position Statement of the ESC Council on Hypertension on ACE-Inhibitors and Angiotensin Receptor Blockers. https://www.escardio.org/Councils/Council-onHypertension-(CHT)/News/position-statement-of-the-esc-council-on-hypertension-on-ace-inhibitorsand-ang. Published 2020. Accessed May 15,2020, 2020.

13. Liberati A, Altman DG, Tetzlaff $\mathrm{J}$, et al. The PRISMA statement for reporting systematic reviews and meta-analyses of studies that evaluate healthcare interventions: explanation and elaboration. $B M J$. 2009;339:b2700.

14. Stroup DF, Berlin JA, Morton SC, et al. Meta-analysis of observational studies in epidemiology: a proposal for reporting. Meta-analysis Of Observational Studies in Epidemiology (MOOSE) group. JAMA. 2000;283(15):2008-2012. 
15. Wells G SB OCD, Peterson J, Welch V,Losos M,tugwell P. The Newcastle-Ottawa Scale (NOS) for assessing the quality of nonrandomised studies in meta-analyses. 2018. Published 2018. Accessed 05/02/2020, 2020.

16. Higgins JP, Thompson SG, Deeks JJ, Altman DG. Measuring inconsistency in meta-analyses. BMJ. 2003;327(7414):557-560.

17. Ip A, Parikh,K., Parrillo,J., Mathura, S., Hansen,E., Sawczuk, I., Goldberg,S. Hypertension and Renin-Angiotensin-Aldosterone System Inhibitors in Patients with Covid-19 Published 2020. Accessed May 15,2020, 2020.

18. Mehta SS, Adoni N, Shihabi A, Bodine C, Moussa I, Gibb M. Multimodality Imaging and Percutaneous Closure of Right Sinus of Valsalva to Right Ventricular Outflow Tract Fistula After Transcatheter Aortic Valve Replacement. J Invasive Cardiol. 2019;31(7):E227-E228.

19. Reynolds HR, Adhikari S, Pulgarin C, et al. Renin-Angiotensin-Aldosterone System Inhibitors and Risk of Covid-19. N Engl J Med. 2020.

20. Mancia G, Rea F, Ludergnani M, Apolone G, Corrao G. Renin-Angiotensin-Aldosterone System Blockers and the Risk of Covid-19. N Engl J Med. 2020.

21. Huh K, Ji W., Kang, M.,Hong, J.,Bae, G.,Lee, R.,Na,Y.,Choi, H.,Gong ,S.,, Jung J. Association of previous medications with the risk of COVID-19: a nationwide claims based study from South Korea. Published 2020. Accessed May 15,2020, 2020.

22. de Abajo F, Rodríguez-Martín, S. , Lerma,V. Use of renin-angiotensin-aldosterone system inhibitors and risk of COVID-19 requiring admission to hospital: a case-population study. The Lancet. 2020.

23. Yan H, Valdes A, Vijay A, Wang S. Role of Drugs Affecting the Renin-Angiotensin-Aldosterone System on Susceptibility and Severity of COVID-19: A Large Case-Control Study from Zheijang Province, China. https://www.medrxiv.org/content/10.1101/2020.04.24.20077875v1. Published 2020. Accessed May 15,2020, 2020.

24. Lambert DW, Yarski M, Warner FJ, et al. Tumor necrosis factor-alpha convertase (ADAM17) mediates regulated ectodomain shedding of the severe-acute respiratory syndrome-coronavirus (SARS-CoV) receptor, angiotensin-converting enzyme-2 (ACE2). J Biol Chem. 2005;280(34):30113-30119.

25. Shen L, Mo H, Cai L, et al. Losartan prevents sepsis-induced acute lung injury and decreases activation of nuclear factor kappaB and mitogen-activated protein kinases. Shock. 2009;31(5):500506.

26. Liu J, Zhang PS, Yu Q, et al. Losartan inhibits conventional dendritic cell maturation and Th1 and Th17 polarization responses: Novel mechanisms of preventive effects on lipopolysaccharideinduced $\quad$ acute lung injury. Int J Mol Med. 2012;29(2):269-276.

27. Yu QH, Guo JF, Chen Y, Guo XR, Du YQ, Li ZS. Captopril pretreatment protects the lung against severe acute pancreatitis induced injury via inhibiting angiotensin II production and suppressing Rho/ROCK pathway. Kaohsiung J Med Sci. 2016;32(9):439-445.

28. Guan WJ, Ni ZY, Hu Y, et al. Clinical Characteristics of Coronavirus Disease 2019 in China. N Eng/ J Med. 2020;382(18):1708-1720. 
29. Lippi G, Plebani M. Laboratory abnormalities in patients with COVID-2019 infection. Clin Chem Lab Med. 2020.

30. Shi S, Qin M, Shen B, et al. Association of Cardiac Injury With Mortality in Hospitalized Patients With COVID-19 in Wuhan, China. JAMA Cardiol. 2020.

31. Bin Abdulhak AA, Kashour T, Noman A, et al. Angiotensin Converting Enzyme Inhibitors and Angiotensin Receptor Blockers and Outcome of COVID-19 : A Systematic Review and Meta-analysis. medRxiv. 2020:2020.2005.2006.20093260.

32. Li Y, Cui LL, Li QQ, et al. Association between ADAM17 promoter polymorphisms and ischemic stroke in a Chinese population. J Atheroscler Thromb. 2014;21(8):878-893.

33. Fan Z, Wu G, Yue M, et al. Hypertension and hypertensive left ventricular hypertrophy are associated with ACE2 genetic polymorphism. Life Sci. 2019;225:39-45.

34. Hoffmann M, Kleine-Weber H, Schroeder S, et al. SARS-CoV-2 Cell Entry Depends on ACE2 and TMPRSS2 and Is Blocked by a Clinically Proven Protease Inhibitor. Cell. 2020;181(2):271-280.e278.

35. Montopoli M, Zumerle S, Vettor R, et al. Androgen-deprivation therapies for prostate cancer and risk of infection by SARS-CoV-2: a population-based study ( $n=4532)$. Ann Oncol. 2020.

36. Richardson S, Hirsch JS, Narasimhan M, et al. Presenting Characteristics, Comorbidities, and Outcomes Among 5700 Patients Hospitalized With COVID-19 in the New York City Area. JAMA. 2020.

\section{Tables}

Table 1: General characteristics of included studies

\begin{tabular}{l|l|l|l|l|l|l|l|l|l|}
\hline ication & Country & Study type & Age & $\begin{array}{l}\text { Males } \\
(\%)\end{array}$ & $\begin{array}{l}\text { Total } \\
\text { cases } \\
\text { N }\end{array}$ & $\begin{array}{l}\text { ACEI N } \\
(\%)\end{array}$ & $\begin{array}{l}\text { ARB N } \\
(\%)\end{array}$ & $\begin{array}{l}\text { Control } \\
\text { N }\end{array}$ & $\begin{array}{l}\text { COVID test positivity } \\
\text { Adjusted OR (95\%CI) }\end{array}$ \\
\hline 12020 & USA & Retrospective cohort study & $\begin{array}{l}64 \text { years } \\
\text { (mean) }\end{array}$ & 58 & 1735 & $116(7)$ & $98(6)$ & 18472 & $\begin{array}{l}\text { ACEI 0.89 (0.72-1.10) } \\
\text { ARB } 1.09(0.87-1.37)\end{array}$ \\
\hline $\mathrm{t}$ al & USA & Retrospective cohort study & $\begin{array}{l}64 \text { years } \\
\text { (median) }\end{array}$ & 50.8 & 5894 & $627(60.1)$ & $664(58.4)$ & 12594 & $\begin{array}{l}\text { ACEI 0.92 (0.79, } 1.08) \\
\text { ARB 1.00 (0.86, 1.15) }\end{array}$ \\
\hline al 2020 & Italy & $\begin{array}{l}\text { Population based case } \\
\text { control study }\end{array}$ & $\begin{array}{l}68 \text { years } \\
\text { (mean) }\end{array}$ & 63.3 & 6272 & $1502(23.9)$ & $1394(22.2)$ & 30759 & $\begin{array}{l}\text { ACEI 0.96 (0.87-1.07) } \\
\text { ARB 0.95 (0.86-1.05) }\end{array}$ \\
\hline 020 & China & $\begin{array}{l}\text { Population based case } \\
\text { control study }\end{array}$ & $\begin{array}{l}48.75 \\
\text { (mean) }\end{array}$ & 51.10 & 610 & $5(0.82)$ & $53(8.69)$ & 48667 & $\begin{array}{l}\text { ACEI 0.65(0.26-1.57) } \\
\text { ARB 0.24(0.17-0.34) }\end{array}$ \\
\hline
\end{tabular}

Abbreviation: ACEI, angiotensin converting enzyme inhibitor, ARB, angiotensin receptor blocker 


\begin{tabular}{|c|c|c|c|c|c|c|}
\hline Study & Exposure & Cases Selection & Control Selection & $\begin{array}{l}\text { Analytical } \\
\text { method to } \\
\text { calculate } \\
\text { adjusted } \\
\text { OR }\end{array}$ & $\begin{array}{l}\text { Factors adjusted } \\
\text { for }\end{array}$ & $\begin{array}{l}\text { Quality } \\
\text { assessment }\end{array}$ \\
\hline $\begin{array}{l}\text { Mehta et } \\
\text { al } 2020\end{array}$ & $\begin{array}{l}\text { ACEI, } \\
\text { ARB }\end{array}$ & $\begin{array}{l}\text { Patients who tested positive for COVId-19 } \\
\text { by PCR from March } 8 \text { to April 12, } 2020 \\
\text { within Cleveland Clinic health system }\end{array}$ & $\begin{array}{l}\text { Patients who tested negative for COVID-19 } \\
\text { based in the same health system }\end{array}$ & $\begin{array}{l}\text { Propensity } \\
\text { score } \\
\text { model }\end{array}$ & $\begin{array}{l}\text { Age, Sex, Co- } \\
\text { morbid conditions }\end{array}$ & $\begin{array}{l}\text { High } \\
\text { Quality }\end{array}$ \\
\hline $\begin{array}{l}\text { Reynolds } \\
\text { et al } \\
2020\end{array}$ & $\begin{array}{l}\text { ACEI, } \\
\text { ARB }\end{array}$ & $\begin{array}{l}\text { Patients who tested positive for COVId-19 } \\
\text { by PCR in the New York University (NYU) } \\
\text { Langone Health electronic health record } \\
\text { from March } 1 \text { to April 15, } 2020\end{array}$ & $\begin{array}{l}\text { Patients who tested negative for COVID-19 } \\
\text { based in the same health system }\end{array}$ & $\begin{array}{l}\text { Propensity } \\
\text { score } \\
\text { model }\end{array}$ & $\begin{array}{l}\text { Age; Sex; Race; } \\
\text { Ethnic group, } \\
\text { Coexisting } \\
\text { conditions, and } \\
\text { medications }\end{array}$ & $\begin{array}{l}\text { High } \\
\text { Quality }\end{array}$ \\
\hline $\begin{array}{l}\text { Mancia } \\
\text { et al } \\
2020\end{array}$ & $\begin{array}{l}\text { ACEI, } \\
\text { ARB }\end{array}$ & $\begin{array}{l}\text { Patients above age of } 40 \text { who tested } \\
\text { positive for COVID-19 in the Lombardy } \\
\text { region in Italy from February } 11 \text { to } \\
\text { March11,2020 }\end{array}$ & $\begin{array}{l}\text { Up to five controls were randomly selected } \\
\text { from the target population of Lombardy to } \\
\text { be matched for sex, age at index date, and } \\
\text { municipality of residence. }\end{array}$ & $\begin{array}{l}\text { Conditional } \\
\text { logistic- } \\
\text { regression } \\
\text { models }\end{array}$ & $\begin{array}{l}\text { Drugs and } \\
\text { coexisting } \\
\text { conditions }\end{array}$ & $\begin{array}{l}\text { High } \\
\text { Quality }\end{array}$ \\
\hline $\begin{array}{l}\text { Yan et al } \\
2020\end{array}$ & $\begin{array}{l}\text { ACEI, } \\
\text { ARB }\end{array}$ & $\begin{array}{l}\text { Patients who tested positive for COVID-19 } \\
\text { by PCR in } 14 \text { hospitals in Zhejiang province, } \\
\text { China from January10 to February } 28,2020\end{array}$ & $\begin{array}{l}\text { All adults from the population } \\
\text { of Gulin town, a suburban area of Ningbo } \\
\text { City, Zhejiang province, China who had } \\
\text { electronic medical record }\end{array}$ & $\begin{array}{l}\text { Logistic } \\
\text { regression }\end{array}$ & Age, Sex, BMI & $\begin{array}{l}\text { High } \\
\text { Quality }\end{array}$ \\
\hline
\end{tabular}

Abbreviation: ACEI, angiotensin converting enzyme inhibitor, ARB, angiotensin receptor blocker

Figures 


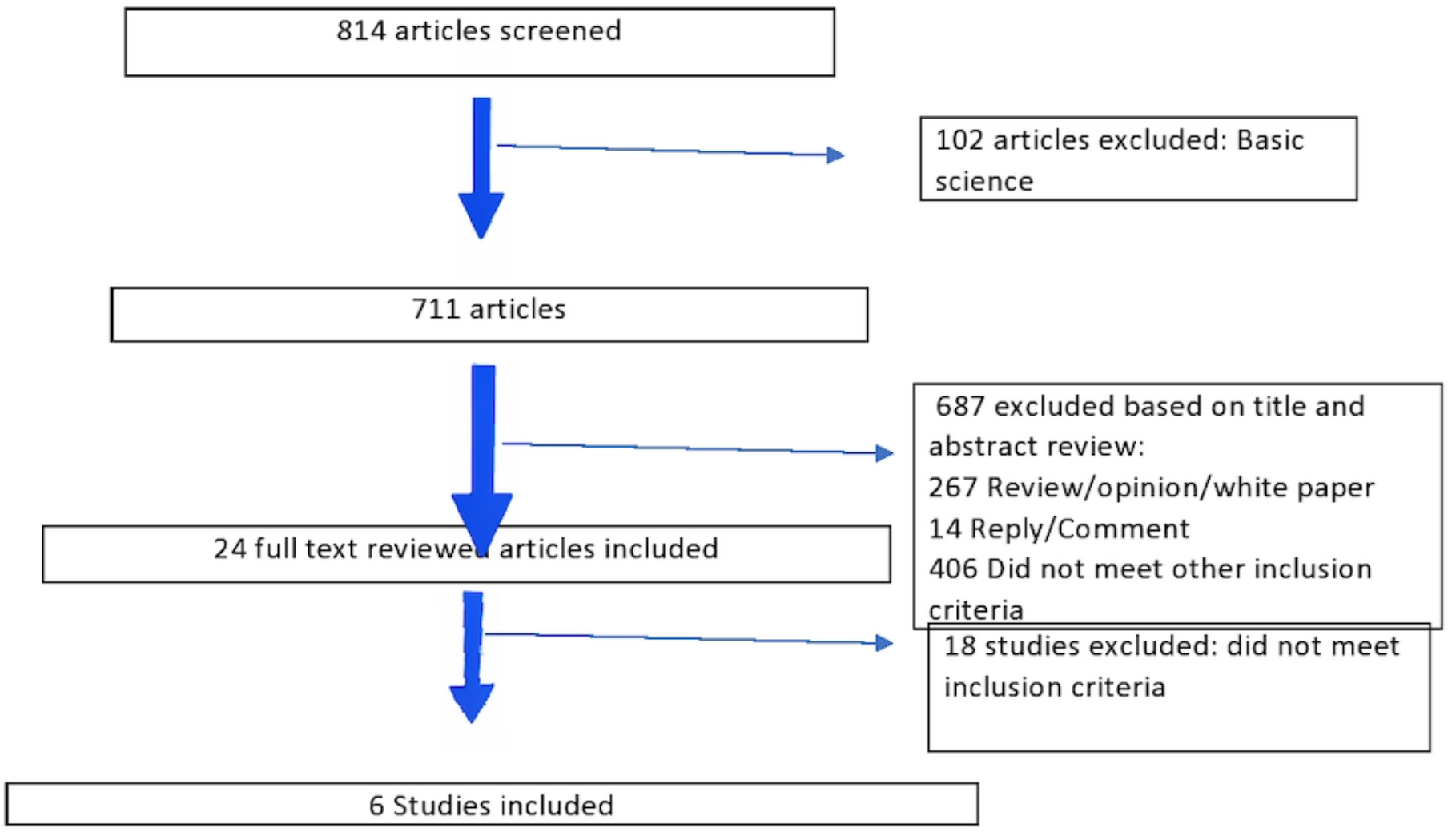

Figure 1

Flow diagram of included studies

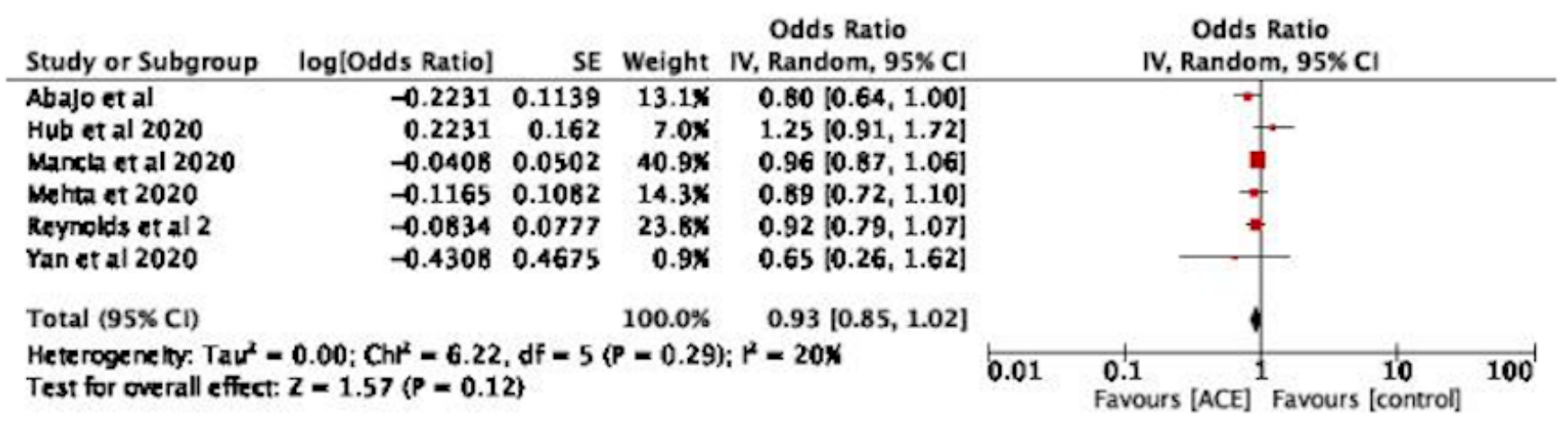

Figure 2

Random effect model meta-analysis of the adjusted pooled effect estimate of the association between ACEls user and risk of COVID-19 


\begin{tabular}{|c|c|c|c|c|c|c|c|c|}
\hline \$tudy or Subgroup & log[Odds Ratio] & SE & Weight & $\begin{array}{l}\text { Odds Ratio } \\
\text { IV, Fixed, } 95 \% \mathrm{CI}\end{array}$ & $\begin{array}{l}\text { Odd } \\
\text { IV, Fixe }\end{array}$ & $\begin{array}{l}\text { Is Ratio } \\
\text { ed, } 95 \% \text { CI }\end{array}$ & & \\
\hline Abajo et al & 0.0953 & 0.1139 & $9.3 \%$ & $1.10[0.8 \mathrm{~B}, 1.3 \mathrm{~B}]$ & & - & & \\
\hline Hub et al 2020 & 0.157 & 0.1063 & $10.7 \%$ & $1.17[0.95,1.44]$ & & $=$ & & \\
\hline Mancla et al 2020 & -0.0513 & 0.0508 & $46.7 \times$ & $0.95[0.86,1.05]$ & & 回 & & \\
\hline wehta et 2020 & 0.0662 & 0.115 & $9.1 \times$ & $1.09[0.87,1.37]$ & & - & & \\
\hline Reynolds et al 2020 & 0 & 0.077 & $20.3 \%$ & $1.00[0.86,1.16]$ & & $\Rightarrow$ & & \\
\hline Yan et al 2020 & -1.4271 & 0.1759 & $3.9 \times$ & $0.24[0.17,0.34]$ & $\rightarrow$ & & & \\
\hline Total $(95 \% \mathrm{CI})$ & & & $100.0 \%$ & $0.95[0.89,1.02]$ & & 1 & & \\
\hline \multicolumn{5}{|c|}{$\begin{array}{l}\text { Heterogene toy: } \mathrm{Ch}^{2}=6 B .52, \mathrm{df}=5(\mathrm{P}<0.00001) ; \mathrm{H}^{2}=93 \mathrm{X} \\
\text { Test for overall effect: } \mathrm{Z}=1.33(\mathrm{P}=0.18)\end{array}$} & $\begin{array}{l}0.1 \\
\text { Favours [ARB }\end{array}$ & 1 Favour & $\begin{array}{l}10 \\
\text { [control] }\end{array}$ & 100 \\
\hline
\end{tabular}

\section{Figure 3}

Random effect model meta-analysis of the adjusted pooled effect estimate of the association between ARBs user and risk of COVID-19 